\title{
The Concepts of Aggressive Information Impact through the Lens of Internet Users' Worldview Security
}

\author{
Elena I. Galyashina and Vladimir D. Nikishin* \\ Kutafin Moscow State Law University (MSAL) \\ Moscow, Russian Federation
}

Received 24.09.2020, received in revised form 19.08.2021, accepted 14.09.2021

\begin{abstract}
This article is devoted to the forensic analysis of the factors (cyberthreats) determining a negative information impact on recipients' worldview in the Internet environment (changes in values, emotional perceptions, and expressions of will, etc.). Findings are founded on the concepts of deviant and delinquent speech behavior, the authors also outline definitions of criminogenic, aggressive, destructive, harmful, conflictogenic, and discrediting (defamatory) information and define the semantic field 'destructiveness of information impact'. The research is based on an interdisciplinary legal and linguistic approach and uses methodology of information law (cyberlaw) and forensic speech science (forensic linguistics) for integral examination of aggressive information products (that are threatening worldview security of Internet communication) in several ways: 1) as speech actions related to law violations (verbal components that reflect actus reus of crimes, administrative offences, and civil torts);2) as a result of communication activity; 3 ) as a source of forensically valuable information. The article covers such worldview security threats as defamation; libel; insult; propaganda of drugs, pornography, gambling, violence and cruelty, murder, autodestructiveness (including suicide), extremism (including terrorism); cyberbullicide; cybersuicide; cybergrooming; sexting; sex blackmail; doxing; outing; faking; astroturfing; cybertrolling; flaming; cyberbullying; cybermobbing; harassment; impersonation; exclusion (ostracism); stigmatization; cyberstalking; threats; hating; 'happy slapping', etc. The authors formulated the list of offenses, entailing the commitment of criminogenic and conflictogenic speech actions (in accordance with the current Russian civil, administrative and criminal legislation), as well as the list of types of information prohibited or restricted in distribution as harmful to the health and development of children (according to the current Russian legislation) are of urgent applied significance.
\end{abstract}

Keywords: destructive communication, information security, worldview security, cyberthreat, destructive information, criminogenic, conflictogenic, discreditation, harmful information, speech act, forensic linguistics, forensic speech science, defamation, insult, propaganda, suicide, extremism, terrorism, bullicide, grooming, sexting, doxing, outing,

(C) Siberian Federal University. All rights reserved

* Corresponding author E-mail address: vdnikishin@msal.ru 
faking, astroturfing, trolling, flaming, bullying, mobbing, harassment, impersonation, exclusion, stigmatization, stalking, threats, hating.

The reported study was funded by RFBR, project number 20-011-00190 («Conceptualization of countering information threats in the Internet environment using special legal and forensic linguistic knowledge»).

Research area: law, linguistics.

Citation: Galyashina, E.I., Nikishin, V.D. (2021). The concepts of aggressive information impact through the lens of internet users' worldview security. J. Sib. Fed. Univ. Humanit. soc. sci., 14(11), 1660-1673. DOI: $10.17516 / 1997-1370-0848$

\title{
Концепты агрессивного информационного воздействия в аспекте информационно-мировоззренческой безопасности интернет-пользователей
}

\author{
Е.И. Галяшина, В.Д. Никишин \\ Московский государственный юридический университет \\ имени О. Е. Кутафина (МГЮА) \\ Российская Федерачия, Москва
}

\begin{abstract}
Аннотация. В настоящей работе на основе специальных юридиколингвистических знаний осуществлен криминалистический анализ факторов (киберугроз), детерминирующих негативное воздействие на мировоззрение реципиента (изменение его ценностных и эмоциональных оценок, волеизъявлений) посредством информационных материалов, распространяемых в интернет-среде. В рамках исследования теоретически детерминированы понятия криминогенной, вредоносной, конфликтогенной и дискредитирующей информации, определено семантическое поле концепта «деструктивность информационного воздействия».
\end{abstract}

Ключевые слова: деструктивное общение, информационная безопасность, мировоззренческая безопасность, киберугроза, деструктивная информация, криминогенный, конфликтогенный, дискредитация, диффамация, вредоносная информация, оскорбление, пропаганда, суицид, экстремизм, терроризм, буллицид, груминг, секстинг, доксинг, аутинг, фейкинг, астротурфинг, троллинг, флейминг, буллинг, моббинг, харассмент, стигматизация, сталкинг, язык вражды, речевое действие, судебная лингвистика, судебное речеведение.

Исследование выполнено при финансовой поддержке РФФИ в рамках научного проекта N20-011-00190 «Концептуализация противодействия информационным угрозам в интернет-среде с использованием специальных юридико-лингвистических знаний».

Научные направления: 12.00 .00 - юриспруденция, 10.02.00 - лингвистика. 


\section{Introduction}

Information, which is distributed in the Internet environment, has such features as materiality, systematicity, inexhaustibility, distance, interactivity, polymodality and mediation, as well as virtuality and virality.

The relative anonymity of cyberspace leads to the fact that delinquents actively use simulacra and other methods of false information and manipulation, while considering themselves outside the field of legal responsibility for these acts (so called phenomenon of social disinhibition (Vasil'ev,2016: 321)).

Worldview security in the Internet environment covers a wide range of public relations which require not only detailed legal regulation but also the development of fundamental innovative approaches to measures of detection, prevention and counteraction to criminogenic speech acts in the Internet environment. We consider the concept of worldview security as a factor of social and political stability based on a natural rights approach.

The counteraction of the phenomena of verbal extremism, cyberbullying, defamation, flaming, faking, and other cyberthreats considered in this study is associated with the risk of restricting the right to freedom of thought, speech and expression. Therefore, this counteraction should be considered in interconnection and interdependence with the rights of others to equality, freedom of religion, protection from discrimination, protection of honor, dignity and other fundamental human and civil rights.

\section{Theoretical framework}

Due to the insufficient development of the concepts of destructive, harmful, criminogenic and other types of aggressive information, there is a need for the theoretical determination of principles and rules for its regulation, as well as innovative criteria for the classification of information materials based on an integrated legal and linguistic approach.

Analysis, systematization and differentiation of these concepts of deviant speech behavior, as well as the construction of a semantic field of destructive informational impact, are necessary within the theory of worldview security of Internet communication and require not just integration, but the synthesis of legal and linguistic knowledge on the basis of forensic speech science.

\section{Statement of the problem}

Determination of the semantic field of the concept of 'destructiveness of information impact' requires the integration of different approaches to the study of concepts of aggressive information impact and a combination of criteria used for worldview security threats (risks) in Internet communication, the classification of information into destructive, criminogenic, conflictogenic, discrediting, harmful, as well as for the classification of speech (communication) strategies and tactics of information impact.

\section{Methods}

The basis of research methodology is the dialectical approach to reality cognition based on the interrelation and interdependence of different phenomena. In this research, the laws of dialectical and formal logic were used along with general scientific methods (observation, description, comparison, systematization, formalization, classification, etc.), special scientific methods (logical, statistical, comparativeanalytical, system-structural, complex and systemic approaches) and logical techniques (analysis, synthesis, induction, deduction, analogy, etc.).

This study is interdisciplinary in nature, providing a synergistic effect from the integration of provisions of information law (cyberlaw), substantive law, criminology, forensic science and applied linguistics - forensic speech science (forensic linguistics). This interdisciplinary approach is necessary for two reasons. Firstly, speech traces, which are addressed under the framework of worldview security of Internet communication, can be defined in several ways: 1) as speech actions related to law violations; 2) as a result of communication activity; 3 ) as a source of forensically valuable information. It should be noted that the term 'speech action' is not equal to the term 'speech act' in the context of forensic speech science. The theory of speech acts has been developed by R. Yakobson (Yakobson, 1985), J. Austin 
(Austin, 1975), J. Searle (Serl', 1986), G. Grise (Grais, 1998) and other linguists. A speech act can be described as "production of a specific sentence for the implementation of a certain communicative intention in certain communication conditions' (Kan, 2015). A speech action reflects the verbal component of actus reus and can include one, two or more speech acts.

Secondly, the distribution of speech acts, which include verbal aggression, can contain actus reus of crimes, administrative offences, and civil torts. Systematization of worldview security threats was based on case law and forensic examinations practice over the period 2015-2020; practices of The Federal Service for Supervision of Communications, Information Technology, and Mass Media (Roskomnadzor) over the period 2013-2018; laws and regulations establishing responsibility for speech acts; academic publications devoted to cyberaggression; and legal regulations of cybersecurity.

\section{Discussion}

We define worldview security of Internet communication as the state of protection of users of the Internet environment, in which there are no content or communication risks tied with information causing harm to health and (or) physical, mental, spiritual or moral development of these users. The threats to the worldview security of Internet communication at the present stage are (Galiashina, Nikishin, 2018):

- cyberbullying is the use of technology to threaten someone, put someone to shame, hurt the feelings of another person, demonstrate hostile attitude applying discriminatory statements related to appearance, intelligence (mental abilities), skills, etc. (See e. g. Willard, 2007; Kowalski, Limber, \& Agatston, 2011) Cyberbullying includes cybermobbing (when someone is being bullied by a group of people), harassment, impersonation, exclusion (ostracism), stigmatization, cyberstalking, threats, happy slapping, online hate.

- trolling is a form of social provocation in the Internet environment that is used both by personalized participants interested in greater recognition, publicity, shocking, and by anonymous users without the possibility of their identification) (See e. g. Hilvert-Bruce, $\&$ Neill, 2020; Napieralski, 2018). Trolling includes flaming (in Internet discourse, this is a situation when the initial dispute topic has long been lost and the communicants are getting the personal treatment, turning the conversation into mutual exercises in backbiting);

- popularization of suicidal and other self-destructive behavior, cybersuicide (cybersuicide flashmob, addictive cybersuicide), cyberbullycide (bringing the victim of cyberbullying to suicide);

- transformation of accounts and communities promoting suicidal ideas into: 1) groups related to the study of information coding mechanisms, 2) movements popularizing the ideas of Satanism (publishing symbols, etc.), as well as 3) communities directly related to the cult of cruelty and violence (publishing shock content and etc.);

- popularization of extremist-terrorist ideology (ideas of separatism, neo-fascism, religious extremism, etc.) (See e. g. Lim, 2020; Nikishin, 2019b; Farkas, Schou, \& Neumayer, 2018);

- open or camouflaged recruitment of minors into radical groups and destructive communities through social networks; illegal missionary activities;

- romanticization of the underground culture, the cult of violence and cruelty (including prison culture); glorification of murderers and suicides through the spread of the 'columbine' subculture ('school shooting', 'roslyakovshchina') (See e. g. Murray, 2017; Slater, 2003);

- cybergrooming (establishing 'friendship and emotional connection with a child or adolescent to gain their trust for the purpose of sexual exploitation' (Soldatova, Chigar'kova, Dreneva, \& Iliukhina, 2019: 91)) and sexting ('a type of virtual communication that includes sending, receiving or forwarding text messages, images, photographs, audio and video recordings of sexual content' (Ibidem: 96));

- sex blackmail ('the threat of publishing intimate photos of the victim in order to extort additional photos, videos or sexual acts' (Ibidem: 12), doxing ('announcement that the 
victim offers sexual services' (Ibidem: 12), outing (posting any kind of information in the public domain, which the victim of persecution did not want and tried to avoid) and digital self-harm (dissemination of defamatory information about themselves in the Internet environment);

- destructive propaganda using fanfiction (a special type of fan art based on the use of any precedent cultural phenomenon: works of literature, cinema, television, gaming industry, etc.). The results of such fan art are published on special thematic sites (ficbook. net, etc.). The main danger is that destructive ideas can be promoted using familiar images and characters of popular (including among minors) works (films, cartoons, etc.). Such familiar images and characters are modified for propaganda purposes, changed to exert a destructive influence on a specific audience (to propagandize violence, Satanism, drug use, pornography, suicide, etc.).

- faking (dissemination of false information for the purpose of propaganda and agitation aimed at distorting facts for political manipulation of the mass consciousness) and astroturfing ('the fifth column of the Internet') - the use of modern software or paid users to organize fake information campaigns online and manage public opinion (for political or business purposes)

- libel, belittling of honor, dignity, business reputation, insult to citizens and legal entities, humiliation of human dignity and discrimination on the basis of language, nationality, sex, religion and other socio-biographical grounds or grounds of physical disabilities.

According to research, more than $50 \%$ of adolescents aged 12-17 years are faced with images of violence, descriptions of methods of excessive weight loss, pornography on the Internet (Ibidem: 11); about $20 \%$ with content about the ways of using drugs and self-harm; about $70 \%$ of adolescents and young people (15-25 years old) faced the propaganda of extremist-terrorist ideology on the Internet (Ibidem: 29-30); about $70 \%$ of adolescents and young people have encountered online propaganda of suicide and self-harm (Ibidem: 109110,140 ); about $60 \%$ of adolescents and young people aged 14-24 years receive information about methods of suicide on the Internet (Syrokvashina, Dozorceva, Badmaeva, Makushkin, \& Shkityr', 2017: 24-31); 10-14 \% of Russian adolescents and young people resorted to self-cutting (Soldatova, Chigar'kova, Dreneva, \& Iliukhina, 2019: 112); about 25 adolescents faced AUE (prison culture) propaganda (Ibidem: 41) and information about drug distribution online (Ibidem: 47); about half of the girls have come across Internet content dedicated to extreme methods of losing weight (Ibidem: 116 ); about half of adolescents and young people $(12-13$ years old $-23 \%, 14-17$ years old $47 \%$, over 17 years old $-54 \%$ ) were subjected to cybergrooming attempts (Ibidem: 92).

The listed threats to the worldview security of Internet communication are associated with manifestations of speech aggression and require consideration through the prism of the concept of destructive communication.

\subsection{Destructive communication}

Considering the concept of destructive communication, Ya. A. Volkova points out that 'the main postulate of destructive communication is «I am the master of the situation, and my interlocutor is a victim, and to hurt him/her by any means is valor» (Volkova, \& Panchenko, 2016: 167).

Destructive communication is considered as 'the forms and features of interactions that adversely affect the interlocutor's personality and complicate the relationships from the perspective of the theory of communication (Kunicyna, Kazarinova, \& Pogol'sha, 2001: 271). In this theory destructive communication includes not only aggressive, conflict and criminogenic communication, but also lies, deception, manipulation and 'other forms of influence directed by selfish motives' (Ibidem: 280).

Considering destructive communication in the cognitive-discursive paradigm, Ya. A. Volkova considers that 'destructive' means not just 'devastating', but 'consciously committing aggressive actions in order to inflict suffering on another individual, while not feeling remorse and receiving satisfaction from the committed acts' (Volkova \& Panchenko, 2016: 168). In the aspect of the research top- 
ic, the satisfaction from the performed actions should not be understood only as a psychological satisfaction of the delinquent with the corresponding destructive accentuations (in this case, the delinquent is confident in his/her own rightness and does not feel responsibility for the harm caused to the victim of his/her aggressive behavior).

Information attacks on the worldview security of Internet users can be performed on the basis of selfish motives with full awareness of their abnormality, incorrectness and perniciousness. In the latter case, speech aggression is aimed at changing the value attitudes of the audience in order to obtain political or other benefits and motivated not by emotions, but by the desire to receive some kind of reward.

In our opinion, this type of destructive communication is covered by the concept of instrumental aggression in the understanding of A. Bass, who singled out 'hostile' aggression (caused by an insult, physical attack or the presence of irritants) and 'instrumental' aggression (the purpose of which is to win a competition or receive a 'reward') (Buss, 1971).

The cognitive strategy of destructive communication can be implemented by integration of various speech (communicative) strategies, i. e. ways of speech behavior in accordance with the intention of the communicant (Borisova, 1999: 89). Within the framework of destructive Internet discourse, the most widespread speech strategies are invective strategy, manipulation strategy, propaganda strategy, discreditation strategy, domination strategy. Each of these speech strategies operates with a certain set of speech tactics, i. e. speech actions aimed at implementing speech strategies.

Analyzing the communicative category of destructiveness in the interdiscursive aspect, Ya. A. Volkova considers the tactics of rudeness and communicative sadism to be completely destructive tactics. 'Communicative sadism is a complex combined destructive tactic that includes techniques / tactics of open (insults, mockery, threats) and latent (systematic pejorative pressure without open manifestation of hostile emotions) verbal aggression, open and latent non-verbal aggression' (Volkova, \& Panchenko, 2016: 168).
Rudeness is 'a combined communicative tactic that includes the techniques of direct and indirect verbal and non-verbal aggression (insult, threat, indignation, ill will, ignorance, etc.), based on the aggressor's impunity and the victim's helplessness (Ibidem). The whole point is in impunity of acts, in that feeling of complete helplessness experienced by victims.

\subsection{Destructive, criminogenic, conflictogenic, discrediting, harmful information: \\ the verge of correlation}

Deviant speech behavior (forms of speech aggression representation) in the digital environment correlates with such concepts as harmful, destructive, conflictogenic, criminogenic, discrediting, etc. information. That is why it is important to differentiate these concepts and determine the semantic field of the concept 'destructiveness of information impact'.

Following E. Fromm's ideas (Fromm, 2004), we consider destructiveness as an extreme form of aggression - 'malignant aggression'. Since the Federal Law 'On the Protection of Children from Information Harmful to Their Health and Development' ${ }^{1}$ appeals to the concept of harm to health and to physical, mental, spiritual and moral development of children, the concept of information 'harmfulness' cannot be ignored.

V.N. Lopatin gives the following definition of the so-called 'harmful information': 'information, dissemination of which harms the society interests, the legitimate interests and rights of citizens' (Lopatin, 2000).

I. L. Bachilo and V.N. Lopatin propose the following classification of harmful information from the perspective of information law:

1) false information;

2) information which includes an infringement of honor, good name and business reputation;

3) information aimed at inciting hatred, enmity and violence;

4) obscene information;

5) information that has a destructive effect on people (Bachilo \& Lopatin, 2001).

\footnotetext{
1 Federal law of the Russian Federation no. 436-FZ of 201012-23 'On Protection of Children from Information Harmful to Their Health and Development'.
} 
It is hardly possible to agree with such an approach to classification due to the absence of a common basis for division: 1) certain types of information, dissemination of which entails legal responsibility, are listed with varying degrees of specification; 2) the first two points of the classification intersect due to the correlation with the concept of 'defamation'; 3) the dissemination of not all 'false information' forms the composition of a civil tort (for example, according to article 152 of the Civil Code of the Russian Federation), an administrative offense (for example, according to article 13.15 of the Administrative Code of the Russian Federation) or a crime (for example, according to article 128.1 of the Criminal Code of the Russian Federation); 4) the description of the fifth type of harmful information can be actually interpreted as 'all types of other information which are not mentioned in the previous clauses', since the phrases 'destructive impact' and 'harmful impact' coincide in meaning: destructive (disastrous) a priori presupposes harm, i. e. destruction and substitution of the value-worldview attitudes of information recipients.

The same inconsistences can be found in V.S. Maurin' classification of harmful information:

1) inappropriate advertising;

2) information that infringes upon honor, dignity and business reputation;

3) obscene information or pornography;

4) information inciting discrimination against the rights and legitimate interests of a person;

5) information that has an unconscious negative impact on human health (Maurin, 2004).

Thus, it is appropriate to consider the concepts of 'harmfulness' and 'destructiveness' of information interchangeably, taking into account that they can cause harm to the health and (or) physical, mental, spiritual, and moral development of recipients.

The dissemination of destructive (harmful) information is a manifestation of deviant speech behavior. Delinquent speech behavior (i. e. entailing legal responsibility deviant behavior) is a part of deviant speech behav- ior that covers speech actions forming actus reus of crimes and administrative offenses or violating forbiddings established in Federal Law 'On the Protection of Children from Information Harmful to Their Health and Development', Federal Law 'On Information, Information Technologies and Information Protection', etc.

Information (that is the result of speechthinking activity within the framework of delinquent speech behavior) has not just harmful but criminogenic nature.

Criminogenity is 'the ability to generate criminality, contribute to its strengthening, expansion' (Efremova, 2000). I.e. criminogenic information is information, creation or dissemination of which entails criminal (more broadly - and administrative) liability because contributes to the increase and expansion of criminality (other forms of illegal behavior), calling for violence and cruelty, murder and propagating extremist-terrorist and other destructive ideology, drug use, etc.

On the other hand, we admit that the proposed term is conditional, since not all criminalized $^{3}$ speech actions contribute to the expansion of unlawful behavior but can generate non-criminalized forms of deviant behavior (self-destructive behavior, engaging in nontraditional sexual relations, etc.) or have the goal of inflicting mental, spiritual, moral suffering on the communicant, without assuming his/her destructive physical actions (intimidation through faking, dissemination of libelous, offensive information, cybertrolling, cyberbullying, etc.).

Any criminogenic information is based on a conflict, i. e. conflict potential ('conflictogenity') is a broader concept in relation to criminogenity. In this regard, the 'etymology' of the concept 'criminogenic speech aggression' (See also Nikishin, 2019a) can be represented as follows (see Scheme 1).

According to the suggested approach, the concept of 'criminogenic speech aggres-

\footnotetext{
2 Federal law of the Russian Federation no. 149-FZ of 200607-27 'On Information, Information Technologies and Information Protection".

3 In this research, we consider criminalization broadly as a phenomenon covering both crimes and administrative offenses.
} 


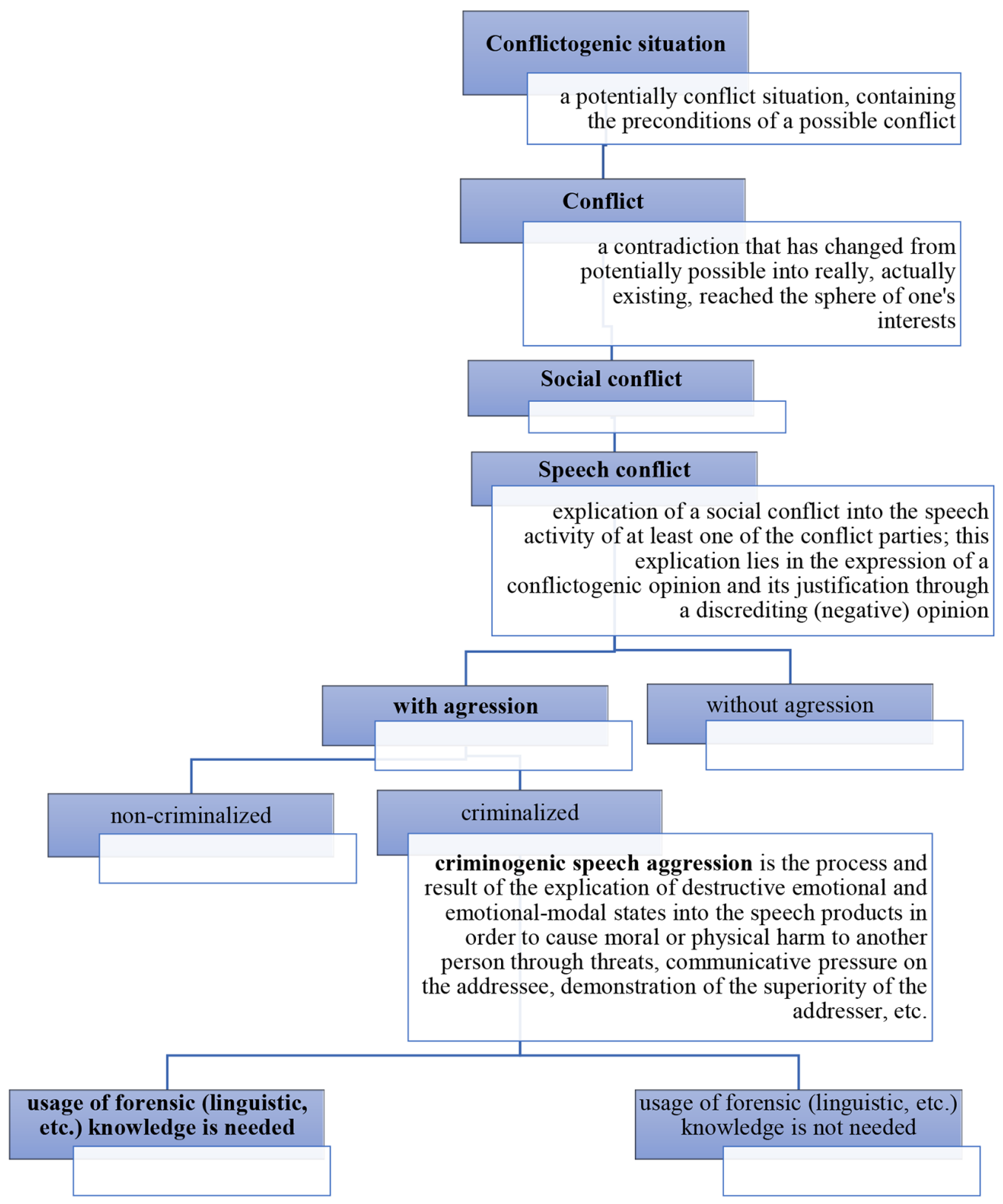

Scheme 1. Criminogenic speech aggression

sion' covers offenses prohibited by any branch of substantive law. However, we propose to use the concepts of 'conflictogenic (conflictgenerating) information', 'conflictogenic speech actions' to characterize communicative situations where speech actions do not constitute actus reus of an administrative offense or a crime, but may serve as a pretext for a civil dis- pute (for example, for filing a defamation claim due to a violation of Article 152 of the Civil Code of the Russian Federation).

We summarized different types of offenses entailing commitment of criminogenic and conflictogenic speech actions (according to the current Russian legislation) (Table 1). Information prohibited or restricted in distribution as 
Elena I. Galyashina and Vladimir D. Nikishin. The Concepts of Aggressive Information Impact through the Lens...

Table 1. List of offenses entailing commitment of criminogenic and conflictogenic speech actions

\begin{tabular}{|c|c|c|}
\hline № & Speech action (speech strategy) title & $\begin{array}{l}\text { Article of Penal Code }(\mathrm{PC}) / \text { Code } \\
\text { of Administrative Violations of } \\
\text { Law }(\mathrm{CAVL}) / \text { Civil Code }(\mathrm{CC})\end{array}$ \\
\hline 1 & $\begin{array}{l}\text { dissemination of untrue information discrediting the honor, dignity, business } \\
\text { reputation of citizens and the business reputation of legal entities }\end{array}$ & $\mathrm{CC}$, art. 152 \\
\hline 2 & insult & CAVL, art. 5.61 \\
\hline 3 & libel & PC, art. 128.1 \\
\hline 4 & libel against a judge, juror, prosecutor, investigator, inquiry officer, bailiff & PC, art. 298.1 \\
\hline 5 & contempt of court & PC, art. 297 \\
\hline 6 & $\begin{array}{l}\text { the dissemination of expressing obvious disrespect for society information } \\
\text { about the days of military glory, as well as committed in public desecration } \\
\text { of the symbols of military glory }\end{array}$ & $\begin{array}{l}\text { PC, art. } 354.1(\text { p. } 3) \\
\text { CAVL, art. } 13.15 \text { (p. } 4)\end{array}$ \\
\hline 7 & insult to a government official & PC, art. 319 \\
\hline 8 & insult to a soldier & PC, art. 336 \\
\hline 9 & $\begin{array}{l}\text { actions expressing clear disrespect for society and committed in order to } \\
\text { insult the religious feelings of believers }\end{array}$ & PC, art. 148 (p. 1) \\
\hline 10 & public appeals to carry out terrorist activities & PC, art. 205.2 \\
\hline 11 & public justification of terrorism & PC, art. 205.2 \\
\hline 12 & propaganda of terrorism & PC, art. 205.2 \\
\hline 13 & public appeals to carry out extremist activities & PC, art. 280 \\
\hline 14 & $\begin{array}{l}\text { public appeals to actions aimed at violating the territorial integrity of the } \\
\text { Russian Federation }\end{array}$ & PC, art. 280.1 \\
\hline 15 & incitement to hatred or enmity, as well as humiliation of human dignity & CAVL, art. 20.3.1; PC, art. 282 \\
\hline 16 & act of terrorist threat & PC, art. 205 \\
\hline 17 & knowingly false reporting of an act of terrorism & PC, art. 207 \\
\hline 18 & $\begin{array}{l}\text { propaganda or public display of Nazi attributes (or symbols), or attributes } \\
\text { (or symbols) of extremist organizations, or other attributes (or symbols), } \\
\text { whose propaganda or public display is prohibited by federal laws }\end{array}$ & CAVL, art. 20.3 \\
\hline 19 & rehabilitation of Nazism (falsification of history) & PC, art. 354.1 (pp. 1-2) \\
\hline 20 & persuading, recruiting or otherwise involving a person in terrorist activities & PC, art. 205.1 \\
\hline 21 & $\begin{array}{l}\text { persuading, recruiting or otherwise involving a person in the activities of an } \\
\text { extremist community or an extremist organization }\end{array}$ & PC, art. art. 282.1, 282.2 \\
\hline 22 & compulsion to acts of a sexual nature & PC, art. 133 \\
\hline 23 & lecherous actions & PC, art. 135 \\
\hline 24 & threat of murder or grievous bodily harm & PC, art. 119 \\
\hline 25 & $\begin{array}{l}\text { threat in connection with the administration of justice or preliminary inves- } \\
\text { tigation }\end{array}$ & PC, art. 296 \\
\hline 26 & inducement to commit suicide & PC, art. 110.1 \\
\hline 27 & organization of activities aimed at inducement to commit suicide & PC, art. 110.2 \\
\hline 28 & $\begin{array}{l}\text { propaganda of narcotic drugs, psychotropic substances or their precursors, } \\
\text { plants containing narcotic drugs or psychotropic substances or their precur- } \\
\text { sors, new potentially dangerous psychoactive substances }\end{array}$ & CAVL, art. 6.13 . \\
\hline 29 & abuse of freedom of the media (faking) & CAVL, art. 13.15 (pp. 9-11) \\
\hline 30 & $\begin{array}{l}\text { placing an advertisement on engagement of children in the creation of in- } \\
\text { formation products that are harmful to their health and (or) development in } \\
\text { information products for children }\end{array}$ & CAVL, art. 6.17 (p. 3) \\
\hline 31 & $\begin{array}{l}\text { violation of the established requirements for the distribution of information } \\
\text { that is harmful to children's health and (or) development (see Table 2) }\end{array}$ & CAVL, art. 6.17 (p. 1) \\
\hline
\end{tabular}


harmful to the health and development of children is given in Table 2 .

As for discrediting information, the destructive intention in the discrediting speech strategy is to harm the honor, dignity, and business reputation of the opponent, i. e. to reduce his/her/its authority in the political, business or other social spheres through the explication of criminogenic speech aggression.

The dissemination of discrediting information may entail both civil law liability (Article 152 of the Civil Code of the Russian
Federation) and administrative liability (Article 5.61 of the Russian Code of Administrative Violations of Law) or criminal liability (Articles 128.1, 298.1, 297, 319, 336, 354.1 of the Criminal Code of the Russian Federation) or not entail any legal liability, while keeping the property of harmful information impact.

Thus, based on the analysis of scientific literature, normative legal acts and expert practice, we determined the ratio of the aforementioned concepts of aggressive information impact in Euler's circles as follows (Fig. 1).

Table 2. Information prohibited or restricted in distribution as harmful to the health and development of children

\begin{tabular}{|c|c|c|c|}
\hline \multicolumn{4}{|c|}{ Information prohibited for distribution among children includes: } \\
\hline 1 & \multicolumn{2}{|l|}{$\begin{array}{l}\text { information encouraging children to commit actions threatening to their life and (or) health } \\
\text { (e. g. to harm to their health, to commit a suicide) or the life and (or) health of other people, } \\
\text { or } \\
\text { information aimed at persuading or otherwise involving children in the commitment of such } \\
\text { actions }\end{array}$} & 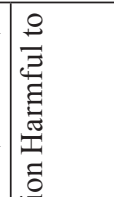 \\
\hline 2 & \multicolumn{2}{|l|}{$\begin{array}{l}\text { information that can make children want to use narcotic drugs, psychotropic and (or) intoxi- } \\
\text { cating substances, tobacco products, alcoholic and alcohol-containing products, to take part in } \\
\text { gambling, to be engaged in prostitution, vagrancy or begging }\end{array}$} & : \\
\hline 3 & \multicolumn{2}{|l|}{$\begin{array}{l}\text { information substantiating or justifying the admissibility of violence and (or) cruelty, } \\
\text { or } \\
\text { information encouraging to carry out violent actions against people or animals (except the } \\
\text { cases provided by the Federal Law) }\end{array}$} & 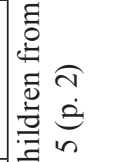 \\
\hline 4 & \multicolumn{2}{|l|}{ information containing an image or description of sexual abuse } & \\
\hline 5 & \multicolumn{2}{|l|}{$\begin{array}{l}\text { information that denies family values, promotes non-traditional sexual relations and forms dis- } \\
\text { respect for parents and (or) other relatives }\end{array}$} & \\
\hline 6 & \multicolumn{2}{|l|}{ information justifying wrongful conduct } & \\
\hline 7 & \multicolumn{2}{|l|}{ information containing obscene language } & \\
\hline 8 & \multicolumn{2}{|l|}{ information of a pornographic nature } & \\
\hline 9 & \multicolumn{2}{|c|}{$\begin{array}{l}\text { information about a minor who has suffered from illegal actions (inactions), including sur- } \\
\text { names, names, patronymics, photo and video images of such a minor, his/her parents and other } \\
\text { legal representatives, the date of birth of such a minor, audio recording of his/her voice, his/her } \\
\text { place of residence or place of temporary stay, the place of his/her study or work, other informa- } \\
\text { tion that allows directly or indirectly to identify such a minor }\end{array}$} & 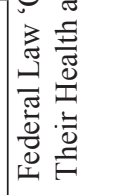 \\
\hline \multicolumn{4}{|c|}{ rmation, the dissemination of which among children of certain age categories is restricted, includes: } \\
\hline & $\begin{array}{l}\text { an image or description of cruelty, physical a } \\
\text { ual violence), crime or other antisocial acts }\end{array}$ & \multirow{4}{*}{\multicolumn{2}{|c|}{ 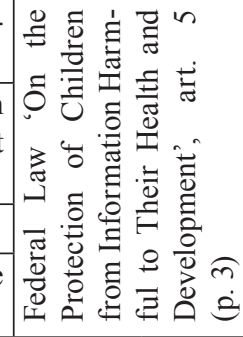 }} \\
\hline 2 & $\begin{array}{l}\text { information that causes fear, horror or pani } \\
\text { (an image or description) presented in a degra } \\
\text { death, an illness, a suicide, an accident or disa }\end{array}$ & & \\
\hline 3 & an image or description of sexual relations between a man and a woman & & \\
\hline & $\begin{array}{l}\text { information contai } \\
\text { language }\end{array}$ & & \\
\hline
\end{tabular}




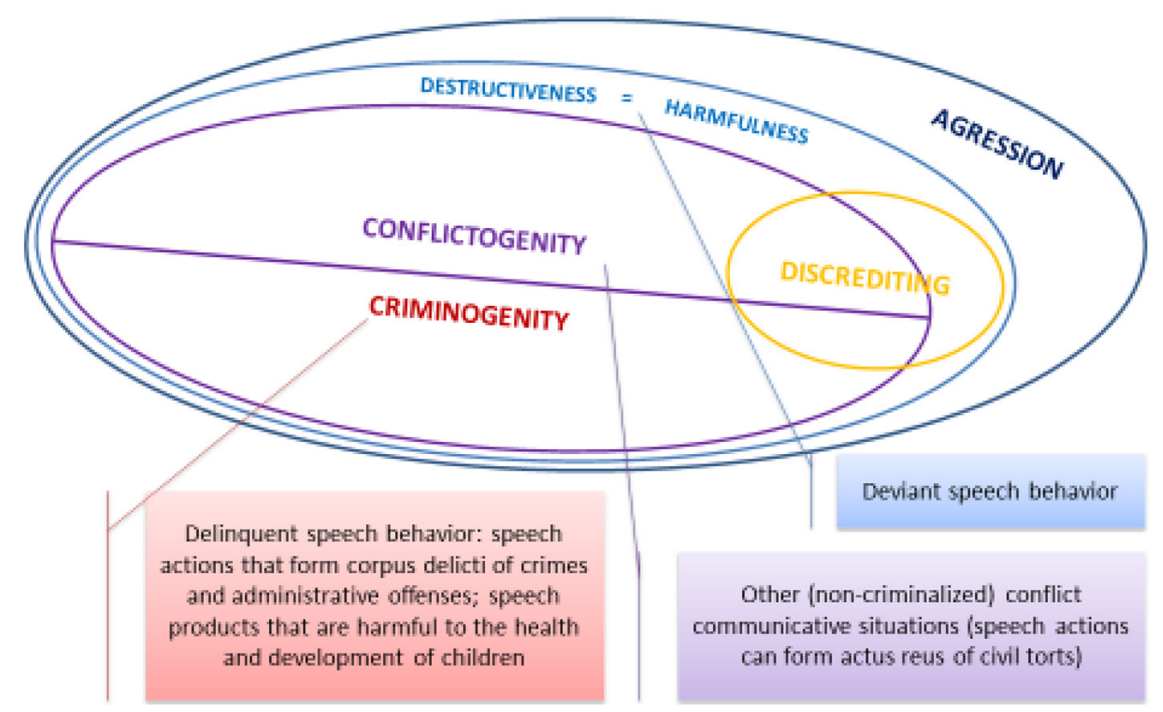

Fig. 1. Concepts of aggressive information impact

\subsection{Semantic field}

\section{of the concept 'destructiveness of information impact'}

G. Ipsen defined a semantic field as 'a set of words with a common meaning' (Ipsen, 1924: 142-225). In other words, a semantic field is 'a hierarchically organized set of lexical and semantic units, integrated by a common concept and reflecting a certain conceptual area' (Fatkullina, 2010: 60). Following V.N. Telia's ideas, we consider a concept as 'knowledge about the designated phenomenon in all its connections and relationships' (Teliia, 1986: 100).

The results of this research show that the semantic field of the concept 'destructiveness (harmfulness) of information impact' has the concepts of 'harm' and 'destruction' in its core and includes the following lexico-semantic groups and subgroups:

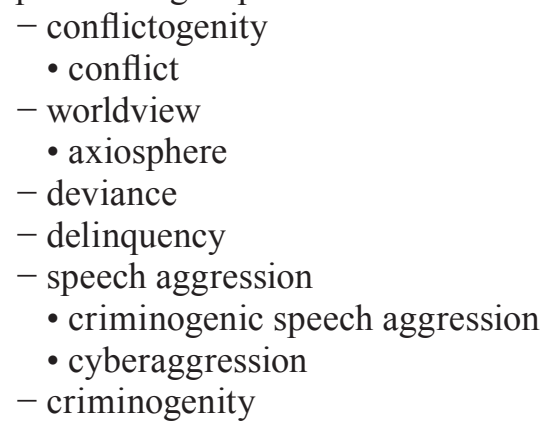

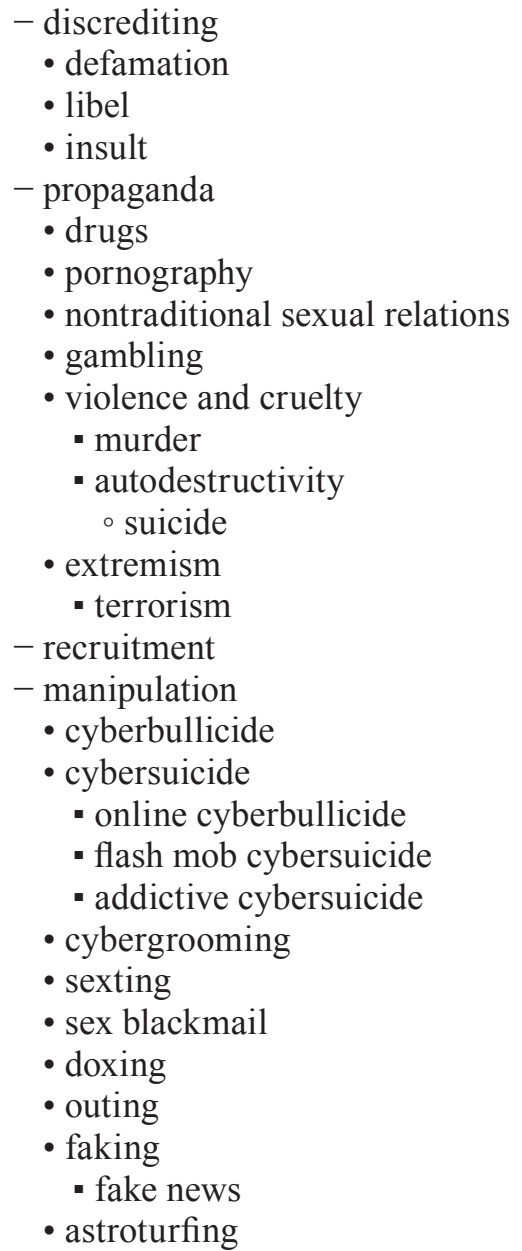




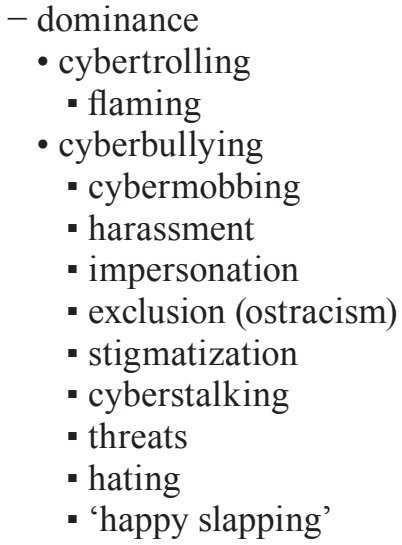

\section{Conclusion}

In this research, we not only summarized current threats to the worldview security of Internet communication and considered the concept 'destructive communication', but also systematically delineated such concepts of deviant speech behavior as destructive, criminogenic, conflictogenic, discrediting and harmful information based on an integrated legal and linguistic approach.
The classification of these phenomena of aggressive information impact is the starting point for the further development of criteria for the classification of information materials in order to ensure the worldview security of Internet communication.

The summarized list of offenses, entailing the commitment of criminogenic and conflictogenic speech actions (in accordance with the current Russian civil, administrative and criminal legislation), as well as the list of types of information prohibited or restricted in distribution as harmful to the health and development of children (according to the current Russian legislation) are of immediate applied significance. Generalization of the concepts included in the semantic field of the concept 'destructiveness (harmfulness) of information impact' is theoretically significant and needs a deeper differentiated study on the basis of the methodology of forensic speech science (forensic linguistics) for the further development of legal and linguistic support of worldview security of Internet communication.

\section{References}

Austin, J. L. (1975). How To Do Things With Words. Oxford University Press, 184 p.

Bachilo, I. L., \& Lopatin, V. N. (2001). Informatsionnoe pravo [Information Law]. St. Petersburg, Iuridicheskii tsentr Press, $789 \mathrm{p}$.

Borisova, I. N. (1999). Kategoriia tseli i aspekty tekstovogo analiza [Purpose Category and Aspects of Text Analysis]. In Zhanry rechi [Genres of Speech], 2, 81-96.

Buss, A. H. (1971). Aggression Pays. In J.L. Singer (ed.), The Control of Aggression and Violence. New York, Academic Press.

Efremova, T. F. (2000). Tolkovyi slovar' Efremovoi [Efremova Explanatory Dictionary]. Available at: https://dic.academic.ru/dic.nsf/efremova/ (accessed 20 April 2020).

Farkas, J., Schou, J., \& Neumayer, C. (2018). Cloaked Facebook Pages: Exploring Fake Islamist Propaganda in Social Media. In New Media and Society, 20 (5), 1850-1867. doi:10.1177/1461444817707759

Fatkullina, F. G. (2010). Koncept 'Destruktsiia' i sposoby ego predstavleniia v russkom iazyke [The Concept 'Destruction' and the Ways of its Presentation in Russian]. In Rusistika [Russistics], 3, 57-66.

Fromm, E. (2004). Anatomiia chelovecheskoi destruktivnosti [Anatomy of Human Destructiveness]. Translated by E. M. Teliatnikova, T. V. Panfilova. Moscow, AST, 635 p.

Fromm, E. (1973). The Anatomy of Human Destructiveness. New York, Holt, Rinehart and Winston, $521 \mathrm{p}$.

Galiashina, E. I., \& Nikishin, V. D. (2018). K voprosu o konceptsii iuridiko-lingvisticheskogo obespecheniia informacionnoi (mirovozzrencheskoi) bezopasnosti v tsifrovoi srede [On the Concept of Legal and Linguistic Support of Information (Worlview) Security in the Digital Environment]. In sbornik nauchnykh trudov Mezhdunarodnoi nauchno-prakticheskoi konferentsii 'Stanovlenie lichnosti v sovremennom obshchestve' [proceedings of the International Scientific and Practical Conference 'Formation of a Personality in Modern Society']. Tomsk, Izd-vo Tomskogo politekhnicheskogo universiteta, 266-269. 
Grais, G. P. (1998). Paradoks kak printsip organizatsii khudozhestvennogo teksta [Paradox as a Principle of Organizing Literary Text]. In Vestnik Sankt-Peterburgskogo universiteta. Ser. 2. Istoriia, iazykoznanie, literaturovedenie [Bulletin of St. Petersburg University. Ser. 2. History, linguistics, literary criticism], 3, 40-50.

Hilvert-Bruce, Z., \& Neill, J. T. (2020). I'm Just Trolling: The Role of Normative Beliefs in Aggressive Behaviour in Online Gaming. Computers in Human Behavior, 102, 303-311. doi:10.1016/j. chb.2019.09.003

Ipsen, G. (1924). The ancient Orient and the Indo-Europeans [Der Alte Orient und die Indogermanen]. In Festschrift für W. Streiber [Festschrift for W. Streiber]. Heidelberg, 142-225.

Kan, A. B. (2015). Teoriia rechevykh aktov v otnoshenii k rechevomu povedeniiu [The Theory of Speech Acts in Relation to Speech Behavior]. Nauka, obrazovanie i kul'tura [Science, Education and Culture], 3 (3). Available at: www.cyberleninka.ru/article/n/teoriya-rechevyh-aktov-v-otnoshenii-krechevomu-povedeniyu

Kowalski, R. M., Limber, S. P., \& Agatston, P. W. (2011). Cyberbullying: Bullying in the Digital Age. Chichester. 294 p.

Kunicyna, V. N., Kazarinova, N. V., \& Pogol'sha, V. M. (2001). Mezhlichnostnoe obshchenie [Interpersonal Communication]. St. Petersburg, Piter, 544 p.

Lim, S. S. (2020). Manufacturing Hate 4.0: Can Media Studies Rise to the Challenge? Television and New Media, 21 (6), 602-607. doi:10.1177/1527476420918825

Lopatin, V. N. (2000). Informacionnaia bezopasnost' Rossii [Information Security of Russia]. Doctor of Law thesis. St. Petersburg.

Maurin, V. S. (2004). Pravovoij analiz vrednoi informacii v usloviiakh informacionnogo obshchestva [Legal Analysis of Harmful Information in the Information Society]. Candidate of Law (PhD) thesis. Moscow.

Murray, J. L. (2017). Mass Media Reporting and Enabling of Mass Shootings. Cultural Studies - Critical Methodologies, 17 (2), 114-124. doi:10.1177/1532708616679144

Napieralski, A. (2018). War of the Internet Users - 'the Hate' in Internet Communication. [La «guerre» des internautes - Le hate dans la communication sur internet]. Linguistica (Slovenia), 58 (1), 173-187. doi:10.4312/linguistica.58.1.173-187

Nikishin, V. D. (2019). Kriminogennaia rechevaia agressiia v aspekte sudebnoi ekspertizy materialov ekstremistsko-terroristicheskoi napravlennosti [Criminogenic Speech Aggression in the Aspect of Forensic Examination of Extremist-Terrorist Materials]. In Vestnik Nizhegorodskogo universiteta im. N.I. Lobachevskogo [Bulletin of N. I. Lobachevsky Nizhny Novgorod University], 3, 108-113.

Nikishin, V. D. (2019). Slovesnyi religioznyi ekstremizm. Pravovaia kvalifikatsiia. Ekspertiza. Sudebnaia praktika [Verbal Religious Extremism. Legal Qualifications. Forensic Expertise. Judicial Practice]. Moscow, Prospekt, $240 \mathrm{p}$.

Serl', Dzh. R. (1986). Chto takoe rechevoi akt?; Kosvennye rechevye akty; Klassifikatsiia rechevykh aktov [What is a Speech Act?; Indirect Speech Acts; Classification of Speech Acts]. In Novoe v zarubezhnoi lingvistike [New in Foreign Linguistics], 17, 151-169.

Slater, M. D. (2003). Alienation, Aggression, and Sensation Seeking as Predictors of Adolescent Use of Violent Film, Computer, and Website Content. In Journal of Communication, 53 (1), 105-121. doi:10.1093/ joc/53.1.105

Soldatova, G. U., Chigar'kova, S. V., Dreneva, A. A., \& Iliukhina, S. N. (2019). My v otvete za tsifrovoi mir: Profilaktika destruktivnogo povedeniia podrostkov i molodezhi $v$ Internete [We are in Charge of the Digital World: Preventing Destructive Behavior of Adolescents and Young People on the Internet]. Moscow, Kogito-Centr, 176 p.

Syrokvashina, K. V., Dozorceva, E. G., Badmaeva, V. D., Makushkin, E. V., \& Shkityr’, E. Iu. (2017). Klinicheskie i psikhologicheskie podkhody $\mathrm{k}$ issledovaniiu problemy suitsidov u podrostkov [Clinical and Psychological Approaches to the Study of the Problem of Suicide in Adolescents]. In Rossijskii psikhiatricheskii zhurnal [Russian Psychiatric Journal], 6, 24-31. 
Teliia, V. N. (1986). Konnotativnyi aspekt semantiki nominativnykh edinits [The Connotative Aspect of the Semantics of Nominative Units]. Moscow, Nauka, $143 \mathrm{p}$.

Vasil'ev, T. (2016). Negativnye aspekty virtual'noi kommunikatsii i ikh pastyrskaia otsenka [Negative Aspects of Virtual Communication and Their Pastoral Assessment]. In Khristianskoe chtenie [Christian Reading], 6, 311-329.

Volkova, Ia. A., \& Panchenko N. N. (2016). Destruktivnost' v politicheskom diskurse [Destructiveness in Political Discourse]. In Vestnik RUDN [RUPF Bulletin. Series: Linguistics], 20 (4), 161-178.

Willard, N. E. (2007). Cyberbullying and Cyberthreats: Responding to the Challenge of Online Social Aggression, Threats, and Distress. Champaign, $320 \mathrm{p}$.

Yakobson, R. O. (1985). Izbrannye raboty [Selected Works]. Moscow. Progress, 460 p. 